\title{
Portuguese Older Gay Men: Pathways to Family Integrity ${ }^{1}$
}

\author{
Filipa Daniela Marques ${ }^{2}$ \\ Instituto Politécnico de Coimbra, \\ Coimbra, Portugal
}

\author{
Liliana Sousa \\ Universidade de Aveiro, \\ Aveiro, Portugal
}

\begin{abstract}
Research in the field of older gay men remains scarce. This exploratory study examines older gay men's experiences in the construction of family integrity (versus disconnection and alienation). The family integrity approach is a developmental perspective that links ego integrity to a larger process of constructing meaning within the family system. The sample comprises ten participants (from 60 to 88 years old). A semi-structured interview was conducted and submitted to content analysis. The main findings suggest three experiences in older gay men's construction of family integrity: (i) influence of homosexuality throughout life; (ii) establishing a family of choice; (iii) creating a legacy associated with homosexuality. Family integrity in older gay men seems to evolve from disclosure at a young age to making homosexuality a legacy in old age.
\end{abstract}

Keywords: old age, homosexuality, family relations, identity

\section{Homens Idosos Homossexuais Portugueses: Caminhos Para a Integridade Familiar}

\begin{abstract}
Resumo: A investigação centrada em homens idosos homossexuais ainda é escassa. Este estudo exploratório analisa especificidades da homossexualidade na construção da integridade familiar (versus desconexão ou alienação). A integridade familiar é uma perspectiva de desenvolvimento que associa a integridade do ego a um processo mais vasto de construção de significado dentro do sistema familiar. A amostra reúne 10 participantes (60-88 anos). A entrevista semi-estruturada foi administrada e submetida à análise de conteúdo. Os principais resultados sugerem três especificidades na construção da integridade familiar: (i) influência da homossexualidade ao longo da vida; (ii) formar uma família de escolha; (iii) formar um legado associado à homossexualidade. A integridade familiar em idosos homossexuais parece evoluir da divulgação (da homossexualidade) na juventude, ganhando ascendência na velhice quando a homossexualidade se torna um legado.
\end{abstract}

Palavras-chave: velhice, homossexualidade, relações familiares, identidade

\section{Hombres Gay Mayores Portugueses: Vías Para Acceder a la Integridad Familiar}

\begin{abstract}
Resumen: La investigación cuanto a los hombres gay mayores sigue escasa. Este estudio exploratorio examina especificidades de la homosexualidad en la construcción de la integridad familiar (vs desconexión o alienación). La integridad familiar es una perspectiva de desarrollo que vincula la integridad del yo con el amplio proceso de construcción de significado dentro del sistema familiar. La muestra reúne 10 participantes ( 60 a 88 años). Una entrevista semiestructurada fue administrada y sometida al análisis de contenido. Los hallazgos sugieren tres especificidades en la construcción de la integridad familiar: (i) influencia de la homosexualidad durante la vida; (ii) formar una familia de elección; (iii) formar un legado asociado con la homosexualidad. La integridad familiar en los hombres gay mayores parece evolucionar de la divulgación (homosexualidad) en la juventud para convertirse en un legado en la vejez.
\end{abstract}

Palabras clave: vejez, homosexualidad, relaciones familiares, identidad

Older homosexual people are still an invisible group and have been relatively ignored in gerontological research (Mabey, 2011). Ageing involves normative challenges that are similar for homosexual and heterosexual people, but there are enough differences to warrant discussion of the homosexual challenges (Barrett, Whyte, Comfort, Lyons,

\footnotetext{
${ }^{1}$ Paper taken from the first author's doctoral dissertation under the second author's supervision, defended in 2013, in the Doctoral Program of Gerontology and Geriatrics at Universidade de Aveiro in cooperation with Universidade do Porto.

Support: Fundação para a Ciência e Tecnologia (Scholarship - SFRH/ $\mathrm{BD} / 45318 / 2008$ ).

${ }^{2}$ Correspondence address:

Filipa Daniela Marques. Escola Superior de Educação de Coimbra - Instituto Politécnico de Coimbra. Portugal. Rua Dom João III - Solum, 3030-329. Coimbra, Portugal. E-mail: fdmarques@esec.pt
}

\& Crameri, 2015). Furthermore, older age has mainly been explored in terms of pathology, dependence and caregiving; however, development is coextensive to life, demanding the study of older people and their families from a developmental perspective (Marques, 2013; Marques \& Sousa, 2011, 2012a, 2012b; Silva, Marques, Santos, \& Sousa, 2010). Family integrity offers a developmental approach to ageing, associating the construction of the self (E. H. Erikson, 1950) with a vaster process of relational development within the family system (King \& Wynne, 2004). Therefore, this exploratory study focuses on older gay men and examines specificities in the construction of family integrity (versus disconnection or alienation). Results are relevant for the better understanding of how homosexuality influences the development and identity of older gay men, particularly regarding their family relationships. 


\section{Ageing and Homosexuality: The Case of Older Gay Men}

Literature that addresses homosexuality and ageing simultaneously is non-extensive and tends to fall into the following topics (Cahill \& Valadéz, 2013; Czaja et al., 2015; Grossman, D'Augelli, \& O'Connell, 2002; Muraco, Le Blanc, \& Russell, 2008; Owen \& Catalan, 2012): (a) myths and stereotypes about older lesbians and gay men; and (b) experiences of gay and lesbian seniors and their families avoiding health and social services in the community out of fear of discrimination. Scarcity of research on homosexual older people has been justified by many reasons (Berger, 1982; Berger \& Kelly, 2002; Minichiello, Plummer, \& Loxton, 2004): (i) gerontology, a young science, has had to deal with some of the many challenges of ageing (such as chronic disease or informal caregiving); (ii) homosexuals, in particular older ones, are still a population difficult to involve in research (mainly due to the fear of discrimination); and (iii) in general, society tends to stereotype older people as "asexual", so that the sexual orientation would be of no interest. Yet, as the aged population increases and a higher numbers of gays, young and older, assert their sexual identity and their rights, knowledge about older homosexuals needs to go deeper.

The current generation of older homosexual people was raised during a historical period when (Barrett et al., 2015; Grossman et al., 2002): (i) they could not share their homosexuality with others without fear (or certainty) of rejection and even persecution; (ii) they were afraid to admit their homosexuality even to themselves, since they had internalized society's negative stereotypes about homosexuality, developing feelings of unworthiness and selfhate. Older homosexuals, who lived their youth under highly discriminative standards, are now facing gradual acceptance of homosexuality, which constitutes a new challenge. For instance, homosexual marriage is now legal (even though not always socially accepted) in many countries (the first country to legalize marriage between members of the same sex was the Netherlands in 2001 and the most recent countries were Ireland and United States of America, in 2015; in the case of Portugal - the country in which this study was undertaken in February 2010), leaving homosexual couples for the first time in a legal relationship.

Studies on ageing families have rarely focused on homosexuality, most probably because it challenges contemporary definitions of family (for instance, there are no norms or appropriate family roles for same-sex relationships) (Istar Lev, 2010a). Family studies tend to focus on homosexuality as a stressor that can disrupt traditional patterns of family life rooted in heteronormative norms (Muraco et al., 2008).

Older homosexuals lived a life of challenges regarding their individual and family identity (Gabrielson, 2011); therefore, it is relevant to better understand how they are constructing their family integrity, which constitutes the older adult's effort to achieve ego integrity, linked to a larger process of constructing meaning and relational development within the family system (King \& Wynne, 2004).

\section{Family Integrity}

Family integrity was introduced by King and Wynne (2004), and associated the construction of the self (E. H. Erikson, 1950) with a vaster process of relational development within the family system. This approach posits that the process involved in attaining ego integrity is inextricably bound up with the broader processes of constructing meaning and relational development at the family level. As such, the process of developing a sense of ego integrity is an individual, subjective experience, taking place within the context of family relationships, which in turn affects perceptions of family integrity.

The process of constructing family integrity is a continuum involving two main pathways (King \& Wynne, 2004): (i) family integrity, which constitutes the positive outcome striving toward meaning, connection, continuity and feelings of satisfaction within the multi-generational family; (ii) family disconnection and alienation (the negative side of this process), which describes a prevailing sense of isolation and disengagement between the older person and his/her family (disconnection), which may achieve a state of lack of family identity (alienation). An older person's ability to achieve family integrity depends on three functions of the family system (King \& Wynne, 2004): transforming family relationships; resolution or acceptance of past losses, disappointments or conflicts; creation of meaning and legacy. Family integrity (versus disconnection or alienation) is an epigenetic process (E. H. Erikson, 1950); it is constructed throughout life, since each stage contributes to the development of the following stages. Thus, individual identity is a hierarchical continuum, starting in the earlier stages of individual and family life cycles, but can only be concluded in later life, as this is the period of "grand generativity" (E. H. Erikson, J. M. Erikson, \& Kivnick, 1986). in which older people assume the role of "keeper of meaning" (embodying traditions of the past, thus providing vital family and social links between the past, present and future; Vailland, 2002).

Marques (2013) and Marques and Sousa (2011, 2012a, $2012 b$ ) studied the processes leading to family integrity (versus disconnection and alienation) considering different contexts. Marques and Sousa (2012a) analyzed life trajectories of elderly persons who had always lived in poverty; the main findings suggested that the risk of family disconnection and alienation is greater in these persons; however, family integrity is achieved by those who develop a philosophy of life that emphasizes the acceptance of the past. Furthermore, Marques and Sousa (2011) examined the trajectories of persons, now elderly, who emigrated and returned to the country of origin (Portugal): former Portuguese emigrants - to understand how life events associated with emigration influenced the construction of family integrity versus family disconnection and alienation. The main findings suggest that maintaining emotional and relational closeness with family during migration periods enriches and protects the sense of family identity, and thus family integrity. This exploratory study examines older gay men's experiences in the construction of family integrity (versus disconnection and alienation). 


\section{Method}

\section{Participants}

The sample (Table 1) comprised 10 gay men between 60 and 88 years old. The sample involved four participants who "work at night", in professions usually associated with gay men (drag queen). Regarding the household composition, five lived alone, four lived with a same-sex partner (one was married); the relationships have lasted from two years to 31 years; and one lived with his mother. Eight reported they had had heterosexual relationships during their lives; one stated he had only had homosexual relations and one did not answer this question. Eight were single (but two were living with a partner) and one was married; one was divorced from a heterosexual marriage. Three participants had children from heterosexual relationships (one had been married; the other two, after their girlfriends got pregnant, decided not to get married due to their sexual orientation).

Table 1

Sample

\begin{tabular}{|c|c|c|c|c|c|c|c|}
\hline Participants & Age & Profession & Household & Academic qualifications & Marital status & $\begin{array}{l}\text { Heterosexual } \\
\text { relationships }\end{array}$ & Children \\
\hline Francisco & 64 & Drag queen & alone & 4 years & Single & Yes & 0 \\
\hline Rodrigo & 61 & Drag queen & with mother & 4 years & Single & - & 0 \\
\hline João & 60 & $\begin{array}{c}\text { Accountant and } \\
\text { drag queen }\end{array}$ & alone & Higher education & Single & Yes & 2 biological \\
\hline Filipe & 60 & Drag queen & alone & 4 years & Single & Yes & Yes \\
\hline António & 65 & Teacher & with husband & Higher education & $\begin{array}{c}\text { Married } \\
\text { (same-sex) }\end{array}$ & Yes & 0 \\
\hline Marco & 88 & Retired teacher & alone & Higher education & Single & Yes & 0 \\
\hline Tomás & 60 & Retired doctor & $\begin{array}{l}\text { with same-sex } \\
\text { partner }\end{array}$ & Higher education & Single & Yes & 0 \\
\hline Paulo & 61 & $\begin{array}{l}\text { Retired national } \\
\text { guard }\end{array}$ & $\begin{array}{l}\text { with same-sex } \\
\text { partner }\end{array}$ & Secondary & $\begin{array}{c}\text { Divorced } \\
\text { (heterosexual } \\
\text { marriage) }\end{array}$ & Yes & 2 biological \\
\hline José & 60 & Entrepreneur & $\begin{array}{l}\text { with same-sex } \\
\text { partner }\end{array}$ & Secondary & Single & No & 0 \\
\hline
\end{tabular}

The criteria for inclusion in this study were: male; selfidentified as homosexual; $\geq 60$ years old. It was decided to include participants younger than 65 years old (the chronological age standard for old age in Portugal) since ageing in this population tends to be perceived as occurring earlier than in the non-gay community; the gay subculture assumes and expects older individuals to fade into the outer perimeters upon evincing the physical signs of aging (Peacock, 2000; Smith, 1982).

\section{Instruments}

The instruments comprised: a questionnaire to collect socio-demographic data (age, profession, household composition, academic level, marital status, previous heterosexual relationships throughout live); and a semistructured interview to explore the construction of family integrity, based on (King \& Wynne, 2004; Marques, 2013; Marques \& Sousa, 2011, 2012a, 2012b; Silva et al., 2010). For this study, one question was added at the end of each domain, focusing on the influence of homosexuality: "Is there any event associated with your homosexuality that you think has influenced (positively or negatively) any of these aspects?"

\section{Procedure}

Data collection. Participants were recruited using a series of procedures. Initially, the first author contacted ten community institutions and non-governmental gay-related organizations in Portugal, aiming to identify and get access to old gay men (aged over 60 years old); all organizations responded that they did not have members with that age. Then, researchers tried to contact known self-identified homosexuals by email provided by the Internet, but received no answers. We then decided to approach participants using the author's personal and social networks, using a snowball approach; researchers' acquaintances with gay contacts identified eligible participants (homosexual men aged $\geq 60$ years old); to those who were available to cooperate with the study, they asked permission to give their telephone number and/ or their e-mail to the researcher. Then, the first author proceeded as previously established; the study objectives and the required collaboration were explained. Some individuals refused to participate. The participants spontaneously provided a number of justifications: due to the study focus on family relationships, they would not feel comfortable talking about it because of current family conflicts. Those who agreed to participate also helped to identify other participants. The interview was scheduled after the first telephone or email contact or after a face- 
to-face meeting and took place in private settings, chosen by the participants (at their homes or work office). Informed consent was obtained. Ten participants were interviewed (Table 1); the interviews lasted between 33 minutes and 84 minutes, and all were conducted by the first author. All participants' names were changed to pseudonyms for confidentiality purposes. Sample collection stopped at ten participants, as no further participants could be identified. Interviews took place between May 2010 and November 2011.

Data analysis. The interviews were audio-recorded, transcribed and subject to content analysis, taking family integrity as the conceptual framework (King \& Wynne, 2004; Silva et al., 2010; Table 3). First, two independent judges (first and second authors) classified each participant into family integrity versus disconnection/alienation, based on (King \& Wynne, 2004; Silva et al., 2010; Table 2): integrity, overall satisfaction with life and family relationships; disconnection, general dissatisfaction with life and family relationships; alienation, separation from the family. The process was as follows: first, each judge independently read the interviews and attributed one route to each participant; then they gathered to compare and discuss their proposals until agreement was reached. The analysis continued to identify the experiences that emerged in older gay men's construction of family integrity. It consisted of a process of successive refining, involving two independent judges (the authors). The process was as follows: (i) the authors started by reading all the interviews and highlighted the participants' features; (ii) then the judges met and discussed the contents; (iii) this process was repeated until agreement was reached. After the data analysis, all participants were contacted to give their opinion and agreement about the study; everyone agreed with the study.

\section{Ethical Considerations}

This particular kind of research does not require the approval of an ethics committee in Portugal. Notwithstanding, the procedures used in this study complied with the ethical guidelines of The Helsinki Declaration.

\section{Results}

Classification among the different routes shows that: seven participants were classified in family integrity and three in disconnection; no participant was classified in the route of alienation (Table 2).

Table 2

Participants' Classification on Sub/categories

\begin{tabular}{|c|c|c|}
\hline Sub/categories & Family Integrity $(n=7)$ & Family disconnection $(n=3)$ \\
\hline \multicolumn{3}{|l|}{ General Integrity } \\
\hline \multicolumn{3}{|l|}{ 1. (Not) coming out } \\
\hline 1.1. Coming out & $\begin{array}{c}\text { Rodrigo, João, António, Marco, } \\
\text { Tomás, José }\end{array}$ & - \\
\hline 1.2. Not coming out & Filipe & Francisco, Paulo, Álvaro \\
\hline \multicolumn{3}{|l|}{ 2. Homosexuality (not) acceptance } \\
\hline 2.1. Self-acceptance & Rodrigo, António, Tomás, José & - \\
\hline 2.2.Self-rejection & João, Marco & - \\
\hline 2.3. Rejection by others & Rodrigo, João, Filipe & Francisco, Paulo, Álvaro \\
\hline 3. Struggling to prove gender identity as male to others & Rodrigo, José & Francisco \\
\hline \multicolumn{3}{|l|}{ Transformation of family relationships } \\
\hline \multicolumn{3}{|l|}{ 4. (Not) coming out influence on family relationships } \\
\hline 4.1. Positive influence & António, Marco, Tomás, José & - \\
\hline 4.2. Negative influence & Rodrigo, João, Filipe & Francisco, Paulo, Álvaro \\
\hline 4.3. Establishing a chosen family & Rodrigo, João, Filipe, António, José & Francisco, Paulo, Álvaro \\
\hline \multicolumn{3}{|l|}{ Resolution of past losses/conflicts } \\
\hline 5. Mutual progressive disengagement after disclosure & Filipe, António & Francisco, Paulo, Álvaro \\
\hline 6. Regrets related with homosexuality & João, Marco & Francisco, Paulo, Álvaro \\
\hline \multicolumn{3}{|l|}{ Creating a Legacy Associated With Homosexuality } \\
\hline 7. Helping other homosexuals & António, Rodrigo & Francisco \\
\hline 8. Disillusion for not fulfilling parents' wishes & - & Francisco, Álvaro \\
\hline
\end{tabular}

Participants' discourses in each pathway showed both differences and similarities: those going through the route of family integrity tended to be more concise and direct when answering the questions; therefore, interviews had a shorter duration (mean of 48.6 minutes; 34 to 84 minutes), while those trailing family disconnection tended to focus on 
family conflicts that were repeated throughout the interview, regardless of the question and commonly punctuated by feelings of anger and/or crying; therefore, interviews had a longer duration (mean of $55.7 ; 46$ to 75 minutes). The similarities are in the topics they (did not) want(ed) to address: all said they were more comfortable talking about themselves and their homosexuality than about their biological family relationships. Overall, data suggests a strong influence of homosexuality throughout participants' lives (Table 3): "Being homosexual has influenced my whole life! But it hasn't influenced me, because I deal well with my sexual orientation and I couldn't live another way" (Rodrigo, 61 years old).

Table 3

Categories and Subcategories

\begin{tabular}{lll}
\hline Categories and subcategories & Definition & Examples \\
\hline
\end{tabular}

General Integrity

1. (Not) Coming out

1.1. Coming out

1.2. Not coming out

\subsection{Self-acceptance}

2.2. Self-rejection

2.3. Rejection by others
(Not) disclosure of homosexuality to the family.

Coming-out decision tends to occur after falling in love which is assumed as the definitive criterion of sexual orientation. Coming out occurs in two forms: i) explicitly: this involves a formal conversation with the parents (usually, coming out first to the mother for help and guidance), or only coming out to a few trusted family members; ii) implicitly: this applies to those who never directly addressed the issue in the family in order to avoid confrontation, although they are sure family knows.

Not coming out is associated with:

(i) fear of rejection from the family, in particular from parents, because it may well cut off relationship (involves avoiding themes around sexuality and dating);

(ii) form of protection of themselves and their relatives, because of societal prejudices. In some cases homosexuality was discovered by the family, causing conflicts.
"I came to Lisbon to study, I fell in love with my boyfriend and I came because it allowed me to live my homosexuality more freely. I live away from them, but I call them every day, and whenever is possible I go there with my partner" (José).

(i)"I would never tell to my parents, why would I hurt them?! I always heard them say that they would rather a dead son than a homosexual son" (Filipe).

(ii) "I never told my parents, I was scared ... until my father saw a photograph of me kissing a boy and drove me out of the home" (Francisco).

2. Homosexuality (not) acceptance Self and others (not) acceptance of homosexuality.

Participants report feeling good/“normal" with their own homosexuality; this tends to occur in particular after finding a partner with whom they share intimacy on a physical, emotional and spiritual level. This is also associated with less worry about exposure.

Participants describe feeling unhappy (related with negative past experiences of rejection from society), embarrassed ("I'm the shame of the family!; João) or regretting (feeling at fault for being gay, as if it was a choice) being homosexual.

Participants feel rejected by others, including family, friends and co-workers, due to their sexual orientation.
"I always dealt well with homosexuality . . . finding my mate, I realized my orientation, ... now everyone knows!" (António).

"I regret that I have dedicated myself only to men, the ideal is bisexuality" (Marco).

"I had to retire due to my choices; prejudice was such that there was not enough to keep me there" (Paulo). 
...continuation

Categories and subcategories as male to others

3. Struggling to prove gender identity

Definition

Participants describe they have a clear gender self-identity as being male with gender-conforming behaviour; however, they feel the need to prove to others that they are men, because society expects gay men to show numerous female traits.

Transformation of family relationships

4. (Not) coming-out influence on the quality of family relationships

Positive influence is associated with: (i) not coming out, since things would be rather bad if they had come out; (ii) coming out explicitly because it promoted more secure and affectionate interactions with parents; strengthened relationships with the family members who had a good reaction and accepted boyfriends; there is a first shock leading to some distance, but the end is

\subsection{Positive influence}

4.2. Negative influence

4.3. Establishing a chosen family

happy, because parents finally accept the son's sexual orientation; (iii) coming out implicitly

because it helps family acceptation.

Acceptance is promoted by family values

(honesty and hard work) and relatives' personality (generous and loyal).

Negative influence (disengagement or cut-off) is associated with coming out or discovery of homosexuality. It is portrayed as a long-term distressing experience, highly influenced by the social prejudice towards homosexuality that confuses the family. It is characterized by: A total separation (cut-off) that compels the gay person to learn to live alone, grieving for family identity.

Some family values - mainly machismo and conservative attitudes - make the acceptation of homosexuality difficult.

It comprises whose without blood ties who view their homosexuality without prejudices.

The gay community emerges as a chosen family, a place to express themselves and feel better (facilitated by the recent increase in the number of gay bars), what is more common for those that have faced family and friends rejection.
"I do not consider myself feminized! I was born a man and men want to die! In my head I'm a man, I'm not a woman! . . . Here at home there are two men who do household chores and help" (Francisco).
"Not telling my parents positively influenced our relationship because they were gradually accepting" (Tomás).

"My mother said she was not interested in whether I was gay or not; what mattered was that I was serious, hardworking and never gave her any grief" (Francisco).

"I lived my teens stuck in the closet, I'm afraid. . . from there I learned to be alone ... Now I have a friendship with the family, not love" (Álvaro).

"My father was one of those macho conservative: A gay son would be a shame for the family! He fainted because it was a shock - no one suspected" (Francisco).

"When we gathered with friends, we listened and shared experiences, and that made us understand better and encouraged us to go ahead ... there (in the gay bar), I can speak as I please; there is my home and I do what I want who feels bad withdraws up! ... When my father kicked me out of the house after discovering my homosexuality, there were not these gay bars and friendships; today everything would be easier" (Francisco).

Resolution of past losses/conflicts Conflicts that emerged in the past but that are still alive

Some relatives have not fully accepted the homosexuality, although they maintain some contact. Disengagement is progressive since the coming out or discovery of the homosexuality.

5. Mutual progressive disengagement after disclosure
For instance: because the family prohibits the gay relative to be acquainted with new family members (such as newborn children or inlaws), the gay relative becomes outraged with that behaviour, leading to a progressive mutual disengagement and consequent family cut-off
"Since they discovered my homosexuality they never talk to me (his ex-wife and his sons), and my grandchildren have been born and they will not let me see them" (Paulo).

"I feel that with the exception of my parents, my family never accepted my homosexuality, and I moved away too" (António). 
...continuation

\begin{tabular}{lc}
\hline Categories and subcategories & Definition \\
\hline Participants regret past decisions or choices \\
related to their homosexuality, in particular: \\
(i) Coming out too early. \\
6. Regrets related to homosexuality \\
(ii) "False" wedding; i.e. had been married \\
because of the social pressure, and \\
subsequently divorced.
\end{tabular}

Creating a Legacy Associated With Homosexuality

7. Helping other homosexuals

\author{
Participants highlight how their \\ homosexuality experience may gain meaning \\ and contribute to others:
}

(i) Intention of helping the younger generations in the coming-out process.

(ii) Desire to be remembered as an example of homosexuality.

Participants report some disillusion for not 8. Disillusion for not fulfilling parents wishes fulfilling their parents' desires, in particular those related to not perpetuating the generation.
Examples

(i) "If I had known, I would have revealed my homosexuality to my parents later, so they would not have been so shocked . . . I regret it, but at 19 you don't always use your head" (João).

(ii) "I married my ex-wife; I was very scared because I had to pretend I liked women . . . but I regret having done it because it hurt her and my children" (Paulo).

(i) "I want to help young, single gay men . . . I'm here to say that you can be gay, happy and fulfilled. If parents do not like it, patience, not worth wasting time trying to be what we are not" (Francisco).

(ii) "I'd like to be remembered as someone who was able to develop a robust, mature and generous relationship with my partner always want what we build" (António).

"My father would have liked me to have given him a grandson, to have got married, and it never happened, and was never going to happen"

(Francisco).

\section{Family Integrity}

All participants mentioned that disclosure was an important and stressful moment (mostly occurring in participants' early twenties), one of the most significant experiences they had had during their entire life course, consisting in revealing their homosexuality to others; these might include parents, other relatives, close friends and/ or the general community (by exchanging expressions of affection towards everyone). All mentioned an intrinsic need to disclose to their family, because it is a pillar from which nothing should be hidden. The disclosure decision is instigated by falling in love, and not just by the assumption of a homosexual identity. "After falling in love for the first time, at my 15 years old, I immediately talked to my parents. It was very difficult because at that time no one talked about homosexuality!" (António, 64 years old).

Six participants in the route of family integrity came out to their parents and/or other relatives: four of them (António, Rodrigo, João, Marco) did it explicitly, involving a formal conversation; the other two (Tomás and José) revealed it implicitly (the family already knew they were homosexual because of their behavior, such as sleeping with their partners in the same bedroom at the parents' home, but the topic was never directly discussed because it would make relatives feel quite uncomfortable). The seventh participant in family integrity (Filipe) did not disclose to his family, but was discovered by the parents (when he was young and dating his boyfriend).

Four participants (Rodrigo, António, José and Tomás) who somehow came out to their parents currently describe secure and affectionate relationships with both parents. These participants who came out described feelings of selfacceptance, associated with a sense of accomplishment, pride and honesty related to their lifestyle and conduct as homosexuals. They stated that they lived their homosexuality without disappointing or embarrassing their family, defining themselves as honest and hard workers, and people who care for the family; therefore, the family accepts them as homosexual. "My mother told me: My son, you never gave me displeasure, you always respected yourself and the others, so, you being gay is irrelevant to me" (Rodrigo, 61 years old).

Coming out seems to be associated with "positive influence in family relationships" and "create a chosen family". A chosen family has blood ties, consisting of friends, partners, co-workers and everyone who unconditionally accepts participants' homosexuality. It functions as a defense ghetto and as a substitutive family who compensates for the less good aspects of family relations and is a balance that makes them feel good.

Participants mentioned a chosen family-based on the support of those who view their homosexuality without prejudices, which was crucial to facilitate (help and guide) the process of disclosure; i.e. the tie with other homosexuals and/or others who unconditionally accept their homosexuality is an important part of selfacceptance, giving strength and courage before and/or after the disclosure. Rodrigo, José and Filipe, who at first faced rejection by their fathers, compensate for these family conflicts with the help of (homosexual) friends. António did not face rejection, but he explains:

When I was a teenager, and realized I was homosexual, there were no role models, I didn't know what being homosexual meant; I needed to have contact with someone like me, feel free, so I went to California . . . to grow up! 
"Create a chosen family" seems to be associated with "self-acceptance". In fact, four of the five participants who mentioned "create a chosen family" (Rodrigo, António, José and Filipe) showed self-acceptance; despite not mentioning a chosen family, Tomás showed self-acceptance.

Their self-acceptance highlights how their homosexuality experience may gain meaning and contribute to others: (i) Intention of helping the younger generations in the comingout process: "I want to help young, single gay men . . . I'm here to say that you can be gay, happy and fulfilled. If parents do not like it, patience, not worth wasting time trying to be what we are not" (Francisco, 64 years old); (ii) Desire to be remembered as an example of homosexuality: "I'd like to be remembered as someone who was able to develop a robust, mature and generous relationship with my partner" (António, 64 years old).

\section{Family Disconnection}

The four participants in the course of family disconnection emphasized that disclosure was very stressful, because the environment was predominantly heterosexual, so they were a minority; this explains why they did not disclose themselves to their relatives. Francisco, Paulo and Álvaro did not come out to their relatives; however, their family members (parents and ex-wives) discovered their homosexuality.

All participants on the path of family disconnection felt they were/are rejected by others (especially at work); for instance, Paulo, an ex-national guard, who interacted with macho men all day long, faced co-workers' pressure that led him to pre-retirement.

Daily rejection by others reinforces: (i) the fear of being rejected by those who are really important (family); (ii) the fear of hurting them, and/or having the family being judged by others. This makes them try to hide their homosexuality until they are discovered.

However, despite good intentions, the discovery of homosexuality is perceived by the family as a betrayal of family members; participants faced rejection and felt misunderstood by relatives, describing conflicts as longlasting. All participants stated that not coming out had a negative influence on family relationships: "The discovery of my homosexuality brought conflicts related with prejudices and disappointment that moved my family away . . . but this happened because they didn't understand me!" (Francisco, 64 years old).

Participants reveal a mutual disengagement after disclosure to relatives who did not accept their homosexuality. This disengagement is accentuated by the disillusion of not fulfilling parents' wishes. Francisco states: “After my father discovered that I was gay, he also knew that I would never give him the grandchildren he wished for ... and that hurt him".

In this context of rejection (by family and by others), participants try to cope by compensating with the support of chosen family members: (i) Francisco goes to gay bars where he can express himself without bias, (ii) Paulo protects himself from the "family conflict" by getting closer with his partner; (iii) Álvaro avoided family contact to be and behave as gay and related with anyone he wanted (so as not to hurt the family with his homosexuality).

\section{Discussion}

This study offers important specificities related to older gay men's construction of family integrity: (i) influence of homosexuality throughout life; (ii) establishing a chosen family; (iii) creating a legacy associated with homosexuality.

\section{Influence of Homosexuality Throughout Life}

The influence of homosexuality during life seems to involve mainly the disclosure event, and the acceptance of one's own homosexual identity. The disclosure event punctuates participants' further life experience, emphasizing the epigenetic nature of family integrity process. It was not possible to tell whether parents' reaction to their adult child's sexual orientation disclosure would still be influencing that child as many as 10-20 years later (Rothman, Sullivan, Keyes, \& Boehmer, 2012); yet, our data strongly suggest that that influence remains until old age.

In general, participants in the route of family integrity had disclosed their sexual orientation to their parents in two main ways: explicitly or implicitly. Some authors (Chaudoir \& Fisher, 2010) believe that the implicit way is not a form of disclosure, which is reserved for verbal revelation. Our participants assumed it to be a form of disclosure, however, chosen or constructed with respect for the feelings of oneself and the others ("the gentlest way"). Still, participants classified in family disconnection did not disclose to parents: most were discovered by parents. Concealing and being discovered (by one's parents or ex-wife) seems to bear the burden of betrayal (include shock, loss and grief, damaged self-esteem and anger), in the sense of being harmed by intentional actions or omissions of a trusted person, comprising disloyalty and dishonesty (Rachman, 2010). Nevertheless, the discovery of homosexuality suggests that parents already suspected (in a more or less conscious way) and were looking for confirmation (Moreira \& Dócolas, 1999). In fact, usually, there are no secrets of this dimension in a family (Imber-Black, 2010).

The disclosure moment is part of the sexual identity development that implicitly involves acceptance of one's homosexual identity and thus allows it to be shared with other individuals (Chaudoir \& Fisher, 2010; Gardner, de Vries, \& Mockus, 2014). Participants in family integrity, who had mostly disclosed to parents, seemed to have previously accepted better both themselves and their sexual orientation. They probably had a more accepting family, which permits more confidence to disclose; some studies suggest that family relations can significantly and positively influence identity expression (Gabrielson, 2011). In general, disclosure is associated with positive influence in family relationships; with a posture of greater honesty and openness, which increases intimacy with the family of origin and leads to a true autonomy and intimacy with partners (Gardner et al., 2014; Moreira \& Dócolas, 1999). In fact, these findings suggest 
that participants' relations with the biological family were maintained with those who accepted their sexual orientation, and restrained with who did not.

Those in family disconnection tended to conceal their homosexual identity while struggling to conciliate their identity by combining being gay and men; the inner experience hiding a concealable stigma has been called a "private hell" (Meyer, 2003). In general, concealing one's stigma is used as a coping strategy, aimed at avoiding negative consequences of stigma, but it can backfire and become stressful.

\section{Establishing a Family of Choice}

Participants from both pathways mentioned a chosen family and underlined its relevance during their lives. It comprises those without blood ties (friends, partners, coworkers; homosexuals or not) who view their homosexuality without prejudices and accept it; it always includes other homosexuals, since it permits having "someone like me" (Domínguez-Fuentes, Hombrados-Mendieta, \& García-Leiva, 2012; Peetz \& Wilson, 2013). Participants recognize the chosen families as necessary regardless of the relationships with the family of origin and play two main functions (Gabrielson, 2011): (i) support, which comprises protection from a harsh, homophobic world, and a means of coping with a socially stigmatized identity (a place of acceptance that facilitates selfacceptance); (ii) role model, i.e. providing interactions with someone who is homosexual. Some implications in terms of redefining family in the contemporary world may lead to the further development of two topics: (i) defining the family beyond legal and blood ties to include just affective connections (the relevance assumed by the chosen family in homosexual people may support the broader recognition of significant ties and also better understand its role in all families); (ii) getting a deeper understanding of norms and appropriate family roles for same-sex relations/families (Istar Lev, 2010b).

\section{Creating a Legacy Associated With Homosexuality}

Creating a legacy is a normative developmental task in old age, associated with the desire to protect the family (particularly the descendants), giving meaning to life (leaving a legacy of values and assets) and symbolically surviving death (making a contribution; King \& Wynne, 2004). Participants (family integrity and disconnection) reveal the desire to leave a legacy (even those who have no descendants), which includes their experience as gay men: being role models for younger homosexuals, and helping them in their disclosure is an altruistic intergenerational contribution by helping young gay men to find their self-identity and cope with stigmatization (Dooley, 2009). This underlines that citizens, practitioners, policymakers and researchers need to move from viewing minority group members as passive victims of prejudice to viewing them as actors who interact effectively with society (Meyer, 2003). In fact, the process of constructing family integrity seems to be a process that comes from disclosure (revealing/assuming homosexuality) to closure (using homosexuality as a legacy).

Older homosexual people are still an invisible group, making them less accessible for research; in particular, they avoid family-related topics. Thus, our study offers the possibility for alternative contemporary understandings of the life trajectories and the construction of family integrity for this common minority group in gerontology research homosexuals. These findings may assist researchers, health professionals and age care services to further understand the needs and experiences of this older generation of gay men.

This study suggests three experiences in older gay men's construction of family integrity: influence of homosexuality throughout life; establishing a family of choice; creating a legacy associated with homosexuality. The main study limitation is the small sample size (10); procedures to recruit larger samples need to be discussed and improved. Difficulty finding participants is a problem that seems to have plagued most research on homosexuality in the past and will most likely persist in the near future; due to the social constraints of a homophobic society, the population under investigation is necessarily hidden. Drawing a sample from a hidden and, to a great extent, undefined population posed a serious problem.

The participants in this study were mostly educated, employed and mostly high-functioning men with considerable social support. Future research should do better at gathering information on all older homosexuals, including low-income and immigrant populations. Future studies need to address lesbians, since research with older women is even scarcer compared to gay older men (Berger, 1982; Grigorovich, 2015).

In general, research needs to enhance the knowledge on how a gay identity alters the family life course. It is also essential to acknowledge the meaning of family for gay people/couples/families, which will facilitate a deeper understanding of contemporary family life.

\section{References}

Barrett, C., Whyte, C., Comfort, J., Lyons, A., \& Crameri, P. (2015). Social connection, relationships and older lesbian and gay people. Sexual and Relationship Therapy, 30(1), 131-142. doi:10.1080/14681994.2014.963983

Berger, R. M. (1982). Gay and gray: The older homosexual man. Urbana, IL: University of Illinois Press.

Berger, R. M., \& Kelly, J. J. (2002). What are older gay men like? An impossible question? Journal of Gay \& Lesbian Social Services, 13(4), 55-64. doi:10.1300/ J041v13n04_07

Cahill, S., \& Valadéz, R. (2013). Growing older with HIV/AIDS: New public health challenges. American Journal of Public Health, 103(3), e7-e15. doi:10.2105/ AJPH.2012.301161

Chaudoir, S. R., \& Fisher, J. D. (2010). The disclosure processes model: Understanding disclosure decision making and postdisclosure outcomes among people living with a concealable stigmatized identity. Psychological Bulletin, 136(2), 236-256. doi:10.1037/a0018193

Czaja, S. J., Sabbag, S., Lee, C. C., Schulz, R., Lang, S., Vlahovic, T., . . . Thurston, C. (2015). Concerns about aging and caregiving among middle-aged and older 
lesbian and gay adults. Aging \& Mental Health. Advance online publication. doi:10.1080/13607863.2015.1072795

Domínguez-Fuentes, J. M., Hombrados-Mendieta, M. I., \& García-Leiva, P. (2012). Social support and life satisfaction among gay men in Spain. Journal of Homosexuality, 59(2), 241-255. doi:10.1080/00918369. 2012.648879

Dooley, J. (2009). Negotiating stigma: Lessons from the life stories of gay men. Journal of Gay \& Lesbian Social Services, 21(1), 13-29. doi:10.1080/10538720802494784

Erikson, E. H. (1950). Childhood and society. New York, NY: W.W. Norton.

Erikson, E. H., Erikson, J. M., \& Kivnick, H. Q. (1986). Vital involvement in old age. New York, NY: W.W. Norton.

Gabrielson, M. L. (2011). "We have to create family": Aging support issues and needs among older lesbians. Journal of Gay \& Lesbian Social Services, 23(3), 322-334. doi:10 $.1080 / 10538720.2011 .562803$

Gardner, A. T., de Vries, B., \& Mockus, D. S. (2014). Aging out in the desert: Disclosure, acceptance, and service use among midlife and older lesbians and gay men. Journal of Homosexuality, 61(1), 129-144. doi:10.1080/0091836 9.2013.835240

Grigorovich, A. (2015). Negotiating sexuality in home care settings: Older lesbians and bisexual women's experiences. Culture, Health \& Sexuality, 17(8), 947-961. doi:10.1080/13691058.2015.1011237

Grossman, A. H., D'Augelli, A. R., \& O'Connell, T. S. (2002). Being lesbian, gay, bisexual, and 60 or older in North America. Journal of Gay \& Lesbian Social Services, 13(4), 23-40. doi:10.1300/J041v13n04_05

Imber-Black, E. (2010). Couple and family therapy and practice: Innovations in 2010. Family Process, 49(3), 265-267. doi:10.1111/j.1545-5300.2010.01322.x

Istar Lev, A. (2010a). A review of gay and lesbian parents and their children: Research on the family life cycle; Who's your daddy? And other writings on queer parenting; Becoming parent: Lesbians, gay men, and family. Journal of GLBT Family Studies, 6(3), 341-348. doi:10.1080/155 0428X.2010.490903

Istar Lev, A. (2010b). How queer! The development of gender identity and sexual orientation in LGBTQ-headed families. Family Process, 49(3), 268-290. doi:10.1111/ j.1545-5300.2010.01323.x

King, D. A., \& Wynne, L. C. (2004). The emergence of "family integrity" in later life. Family Process, 43(1), 7-21. doi:10.1111/j.1545-5300.2004.04301003.x

Mabey, J. E. (2011). Counseling older adults in LGBT communities. The Professional Counselor: Research and Practice, 1(1), 57-62. doi:10.15241/jem.1.1.57

Marques, F. D., \& Sousa, L. (2011). Trajetórias de vida de pessoas idosas ex-emigrantes Portugueses: A construção da integridade familiar [Emigration trajectories of former Portuguese emigrants: The construction of family integrity]. Revista Kairós Gerontologia, 14(3), 3-24. Retrieved from http://revistas.pucsp.br/index.php/kairos/ article/view/10049/7576

Marques, F. D., \& Sousa, L. (2012a). Integridade familiar: Especificidades em idosos pobres [Family integrity: Pathways of elderly poor persons]. Paidéia (Ribeirão Preto), 22(52), 207-216. doi:10.1590/S0103$863 X 2012000200007$

Marques, F. D., \& Sousa, L. (2012b). Construção da integridade familiar em pessoas idosas pobres: Valores e significados [Family integrity and old age poverty: Values and meanings]. Psicólogo InFormação, 16(16), 11-43. doi:10.15603/2176-0969/pi.v16n16p11-43

Marques, F. D. C. (2013). Famílias envelhecidas: Percursos e diversidade [Ageing families: Pathways and diversity] (Doctoral dissertation). Retrieved from http://ria.ua.pt/ bitstream/10773/13373/1/tese $\% 20 \% 282 \% 29$.pdf

Meyer, I. H. (2003). Prejudice, social stress, and mental health in lesbian, gay, and bisexual populations: Conceptual issues and research evidence. Psychological Bulletin, 129(5), 674-697. doi:10.1037/0033-2909.129.5.674

Minichiello, V., Plummer, D., \& Loxton, D. (2004). Factors predicting sexual relationships in older people: An Australian study. Australasian Journal on Ageing, 23(3), 125-130. doi:10.1111/j.1741-6612.2004.00018.x

Moreira, A. Z. M., \& Dócolas, G. M. G. (1999). A voz do segredo: Homossexualidade na família [The voice of the secret: Homosexuality in the family]. Pensando Familias, 1(1), 56-61. Retrieved from http://www.domusterapia. com.br/pdf/PF1ZucchiDocolas.pdf

Muraco, A., Le Blanc, A. J., \& Russell, S. T. (2008). Conceptualizations of family by older gay men. Journal of Gay \& Lesbian Social Services, 20(1-2), 69-90. doi:10.1080/10538720802178957

Owen, G., \& Catalan, J. (2012). 'We never expected this to happen': Narratives of ageing with HIV among gay men living in London, UK. Culture, Health \& Sexuality: An International Journal for Research, Intervention and Care, 14(1), 59-72. doi:10.1080/13691058.2011.621449

Peacock, J. R. (2000). Gay male adult development: Some stage issues of an older cohort. Journal of Homosexuality, 40(2), 13-29. doi:10.1300/J082v40n02_02

Peetz, J., \& Wilson, A. E. (2013). Waving the flag (or not): Consequences and antecedents of social norms about ingroup identification. Self and Identity, 12(4), 447-466. do i: $10.1080 / 15298868.2012 .698059$

Rachman, S. (2010). Betrayal: A psychological analysis. Behaviour Research and Therapy, 48(4), 304-311. doi:10.1016/j.brat.2009.12.002

Rothman, E. F., Sullivan, M., Keyes, S., \& Boehmer, U. (2012). Parents' supportive reactions to sexual orientation disclosure associated with better health: Results from a population-based survey of LGB adults in Massachusetts. Journal of Homosexuality, 59(2), 186-200. doi:10.1080/0 0918369.2012 .648878

Silva, A. R., Marques, F., \& Santos, L., Sousa, L. (2010). Construindo a integridade familiar no fim da vida [Constructing family integrity in later life]. Psychologica, 
53(3), 109-129. Retrieved from http://iduc.uc.pt/index. $\mathrm{php} /$ psychologica/article/viewFile/1082/530

Smith, E. J. (1982). Counseling psychology in the marketplace: The status of ethnic minorities. The Counseling Psychologist, 10(2), 61-68. doi: $10.1177 / 0011000082102010$

Vailland, G. E. (2002). Aging well: Surprising guideposts to a happier life from the landmark Harvard study of adult development. Boston, MA: Little, Brown.

Filipa Daniela Marques is an Adjunct Professor at Escola Superior de Educação de Coimbra of the Instituto Politécnico de Coimbra, and a Researcher at UNIFAI/CINTESIS (Center for Health Technology and Services Research).

Liliana Sousa is an Auxiliary Professor at the Universidade de Aveiro and member of CINTESIS (Center for Health Technology and Services Research).

Received: May 15, 2015

1st Revision: Sep. 18, 2015

Approved: Oct. 6, 2015

How to cite this article:

Marques, F. D., \& Sousa, L. (2016). Portuguese older gay men: Pathways to family integrity. Paidéia (Ribeirão Preto), 26(64), 149-159. doi:10.1590/1982-43272664201602 